\title{
Teachers' Instructional Strategies and Students' Learning Styles at Northern Quezon College Incorporated: Basis for an Intervention Program
}

\author{
Jay Morilla De Loreto ${ }^{1}$ \\ ${ }^{1}$ Northern Quezon College Incorporated (NQCI), Quezon Province, Philippines \\ Corresponding Author: Jay Morilla De Loreto, Northern Quezon College Incorporated (NQCI), Quezon \\ Province, Philippines. \\ Email: jaydeloreto@yahoo.com.ph
}

Received: January 16, 2019

Accepted: February 27, 2019

Online Published: March 1, 2019

doi: 10.23918/ijsses.v5i3p246

\begin{abstract}
This research investigation focused on the teachers' instructional strategies and the students' learning styles at Northern Quezon College Incorporated, Infanta, Quezon for purposes of identifying and analysing the teaching strategies that significantly relate and match with the learning styles of the students. The descriptive-correlational method of research coupled with informal interviews was used. Data were gathered by means of a validated survey instrument consisting of two sets of questionnaires and supported by open-ended questions. The questionnaires employed a 5-point scale. The data were gathered from 324 randomly selected bona fide students of the college. The data were statistically treated using the appropriate statistical tools and comprehensively interpreted and analysed. As a result of this study, a faculty development program geared at enhancing the teachers' instructional strategies in consideration to the students' learning styles.
\end{abstract}

Keywords: Teachers' Instructional Strategy, Students' Learning Style, Intervention Program, Multiple Intelligence, Learning, Teaching, Faculty, Student

\section{Introduction}

The role of tertiary education is to promote relevant and quality higher education. With this end in view, the Commision on Higher Education (CHED) in the institutions are at par with international standards. The graduates need to be globally recognized Philippines ensures that the programs, activities and services in higher education are competitive. To support this aim, concentration on both teaching and learning is imperative.

It is undeniable that teaching and learning are interrelated processes that largely affect the learners' performance. Thus this study took into consideration the said two important variables which are exceptionally associated with the teaching-learning process. To foster learning, teachers should be armed with a reservoir of diverse instructional strategies as a means of delivering effective instruction for the success of students. Side by side with an effective instruction is the recognition of learners' learning diversity to promote quality learning. Lai and Yap (2016) on their study on multiple intelligences stress that the teachers' instructional strategies should best fit the students' learning styles; in particular subject areas which is the central concern of this study. 
This study investigated the relationship between the teachers' instructional strategies and the students' learning styles. Both are crucial in establishing a conducive learning atmosphere which gives learners the opportunities to become holistically developed.

Specifically, the information provided by this study would be of great significance to the school administrators as a springboard in formulating development programs, seminar-workshops and trainings in retooling their teaching workforce. The teachers themselves could be guided by the information given regarding their teaching strategies. In fact, it is crucial in preparing the most concrete, relevant, functional and responsive instructional strategies which are aligned with the learning styles of the students. Most importantly, the students could benefit largely from this research because they are the centers of the educative process.

\subsection{Background of the Study}

Education plays a very important role in an individual's life. Indeed, it is integral to the continuous development of a person to be able to contribute to the country's progress. Every country strives hard to provide all possible means in educating their youth, specifically, in providing them the knowledge, skills and values that they need to help build their respective societies.

In the Philippines, the government is continuously exploring all possibilities to provide its citizens particularly the youth, the next generation to lead this country, the required quality education that would develop humane and contributing citizens to nation building. This is embodied in Section 1 Article 14 of the 1987 Constitution which provides that "the State shall protect and promote the right of all citizens to quality edcuation at all lelvels." This is supported by Section 2 of Republic Act 7722 also known as the Higher Education Act of 1994 which mandates that "the State shall protect, foster and promote the right of all citizens to affordable quality education at all levels".

The study of Abuel (2013) discussed that although there were "several innovations and reforms in both basic and higher education, studies reveal that the educational system is continuously declining. This is evidenced by the results in national licensure examinations and the achievement scores of Filipino students compared to the international average. In the Trends in International Mathematics and Science Study (TIMMS) conducted in 2003, the average score of the Filipino students in Science is 332, which is 157 less than the international average of 489 . Out of the 25 participating countries, the Philippines ranked 23rd or third to the last. In the same study, the scores of the Filipino students in Mathematics is 358 , far below the international average which is 495. Again, the Philippines ranked 23rd out of 25 participating countries. Further in a study done by TIMMS in 2008 involving the performance of students in Advanced Mathematics, the results showed that the scores of the Filipino students is 355 which is much lower than the international average of 495. Out of the 10 participating countries, the Philippines ranked 10th or last.

In the advent of the 21st century when the terms "Education for All (EFA 2015)", "contemporary education", "21st century learning skills", and "learner- centered classroom and approach" were the foremost trends in education. It is expected that all educators especially the teachers are equipped with the necessary contemporary knowledge, skills and values to able to give these same things to their students. 
Among others, the teacher is a vital factor in effecting quality education. He/she is the primary key to instruction and manages how students learn during the teaching-learning process. He/She is the orchestrator and facilitator of learning and guides the students in the achievement of learning objectives. As such, the teacher must be adequately and properly equipped with all the necessary qualifications, preparations and requirements of an effective teacher.

A lot of researches were done concerning the teaching-learning process. One such study was done by Wilson (2011) in her research entitled "Students' learning style preferences and teachers' instructional strategies: correlation between matched styles and academic achievement." The author found that the findings demonstrate weak, if any, correlation between students' academic achievement and degree of match in learning style preferences and accommodations. It is recommended that further studies investigating learning style preferences need to take careful precautions to protect against the design and data flaws exposed in this study. Impliedly, Wilson (2011) states the study failed to provide strong empirical evidence.

Based on the above, this present study was conceptualized. There is a need to focus on how learners learn through a multitude of teachers' instructional strategies which are applied in the different learning areas in consideration to the students' learning styles. If this study is not done, there would be no concrete, valid and reliable guidelines in improving the holistic dimensions of students' life. Educators could hardly percieve the appropriate strategies to be dealt with concerning the delivery of instruction, the improvement of students' performance, behaviour and learning outcomes. This would pose a great step towards achieving the success of the teaching-learning process - a mutual process - for the realization of the State's missions which are thoroughly emphasized in the 1987 Constitution.

The study's objectives are as follows: (1) describe the teachers' instructional strategies and students' learning styles at Northern Quezon College Incorporated; (2) explain the correlation between these variables; (3) predict if there is a significant relationship between these variables; and (4) make inferences and suggest possible solutions for the improvement of the teaching-learning process.

\subsection{Statement of the Problem}

Efficient and effective instructional strategies help teachers in developing the learners' holistic aspects. The improvement of the latter's cognitive, affective and psychomotor domains are deemed important and inevitable in the process. Moreover, students' learning styles have great impacts on their holistic development.

This study aimed to investigate the teachers' instructional strategies and students' learning styles at Northern Quezon College Incorporated for Schoolyear 2016-2017.

Specifically, this study sought answers to the following questions:

1. What is the profile of the student-respondents in terms of the following:

- Age

- Gender

- Year Level 
- Residence

- Course

2. What are the instructional strategies employed by the teachers as assessed by the students in terms of:

- Clarity

- Creativity

- Enthusiasm

- Openness

- Organization

- Relevance

3. What are the students' learning styles as assessed by the students themselves in terms of:

- Logical Learning

- Physical Learning

- Solitary Learning

- Verbal Learning

- Visual Learning

4. How do the teachers' instructional strategies relate with the learning styles of the students?

5. What are the problems encountered by the students in terms of their teachers' instructional strategies and their learning styles?

6. Based on the findings of the study, what program can be designed which is aimed at retooling the faculty in terms of their instructional strategies in consideration to the students' learning styles?

\subsection{Hypothesis}

There is no significant relationship between the teachers' instructional strategies and the students' learning styles

\subsection{Assumptions}

1. Teachers' instructional strategies and students' learning styles are constructs that can be measured.

2. All respondents of the study are bonafide students of Northern Quezon College Incorporated.

\subsection{Scope and Delimitations}

The study was conducted at Northern Quezon College Incorporated (NQCI) in the second semester of School Year 2016-2017 with concentration on teachers' instructional strategies and the relation of this variable to the students' learning styles.

The main tool in gathering the data is a validated researcher-designed survey instrument which was enhanced by open-ended questions. 
Teachers' instructional strategies covered areas like Clarity, Creativity, Enthusiasm, Openness, Organization, and Relevance while the students' learning styles covered areas such as: Logical Learning, Physical Learning, Solitary Learning, Verbal Learning, and Visual Learning.

Basic Education students as well as first-year college students were not taken as respondents; only college students from second year to fourth year regardless of program since they have already observed their teachers' instructional strategies for a reasonable period of time. Additionally, these students are aware enough and are able to determine and describe their learning styles.

\section{Review of Related Literature and Studies}

This chapter presents the reviewed related literature and studies which are closely related to this study. The researcher analyzed and synthesized the past attempts concerning the variables of this research. Thematic organization and analysis was used. The researcher summarized the previous conceptual literature and research literature or study, followed by a critical analysis on the subject of study. Specifically, the review focuses on the relationship between teachers' instructional strategies and students' learning styles. These two are the themes which are mainly considered in this chapter.

To make this review more organized and comprehensive, this chapter is divided into two main sections. The first section summarized and analyzed related literature and studies to the first variable of the present study which is teachers' instructional strategies. The second section, on the other hand, is focused on the second variable of the study which is students' learning styles.

\subsection{Teachers' Instructional Strategies}

"Instructional Strategies Motivate and Engage Students in Deeper Learning" (2013), stresses that instructional strategies are becoming increasingly diverse as teachers tap students' interests and abilities to help them absorb academic and career/technical subjects that will improve their chances of success in college and in their chosen careers. Teachers give difficult assignments that require the interaction among students in displaying creative ideas, problem solving and research skills as they learn the contents essential to succeed in life. Technology has been a boon to teachers and students in making learning "come alive" to hold the interest of all students. In fact, Bonwell and Eison (2010) posit that active learning instructional strategies include a wide range of activities that share the common element of involving students in doing things and thinking about the things they are doing. Further, Eison (2010) asserted that active learning instructional strategies can be created and used to engage students in (a) thinking critically or creatively, (b) speaking with a partner in a small cluster or with the whole class, (c) expressing ideas through writing, (d) exploring personal attitudes and values, (e) giving and receiving feedback, and (f) reflecting upon the learning process. It should also be noted that active learning instructional strategies can (a) be used either in-class or out-of-class, (b) be done by students working either as individuals or in groups, and (c) be done either with or without employing technology tools.

In addition, when an instructor employs active learning strategies, he or she will typically (a) spend a greater proportion of time helping students develop understanding and skills (promoting deeplearning) and a lesser proportion of time in transmitting important information (i.e.supporting surface learning). Furthermore, the instructor provides opportunities for students to (a) apply and demonstrate what they 
are learning and to (b) receive immediate feedback from peers and/or from the instructor (Eison, 2010). On the subject of the social and cultural factors affecting educational achievement motivation, academic atmosphere of the university had the greatest impact. However, it was disclosed that the scientific atmosphere of the university smooths the way for students to be more motivated to learn, which in turn, can motivate students to learn and improve academic achievement. Geo-regional factors affect educational achievement motivation, 'green and refreshing milieu of the University' had a substantial impact on educational motivation. For Chiu and Chow (cited in Taheri et al., 2015), success was higher for students who had a family with a culture of higher educational achievement. In this regard, Taheri et al. (2015) showed that parents' education had a positive effect on their children's educational motivation.

\subsection{Students' Learning Styles}

Studies on learning styles vary depending on their specific subject matters. Asadipiran (2016) made a study on young learners' learning styles. This study purposively identified the preferred perceptual learning styles of Iranian young learners. To accomplish this aim, a Perceptual Learning Style Preference Questionnaire (PLSPQ) was used to measure the students' preferred learning styles. The participants of the study were 60 high school students; all are male first- year high school at Tehran, Iran. The study revealed that visual learning (30\% of the participants) was the most preferred. However, the less preferred was group learning style (5\%). The second to fifth place belonged to tactile (25\%), auditory $(20 \%)$, individual (15\%) and kinaesthetic (10\%) learning style, respectively.

Another study focusing on perceptual learning style was published by Nosratinia and Soleimannejad (2016). This study attempted to systematically inspect the association between learners' critical thinking on English as a Foreign Language (EFL), on one hand, and their total score of perceptual learning styles, various perceptual learning styles, and number of main perceptual learning styles, on the other hand, the obtained results indicated that there have been important and positive relationships between the participants' critical thinking and their total score in sensory activity learning styles, critical thinking and the number of major perceptual learning styles, and critical thinking and group, visual, auditory, tactile, and kinaesthetic perceptual learning styles. Furthermore, a multiple regression analysis was run which revealed that tactile learning style preference is the best predictor of EFL learners' critical thinking.

A study by Kadir (2013) in MARA Professional Colleges in Malaysia revealed that the environmental factors do not directly contribute to academic achievement. However, the study showed that the instructional environment do affect the processing skills and brain behaviour of the students. In fact, redesigning the instructional environment into a totally responsive atmosphere could improve the attention of the students in class (Pizzo, Krimsky, \& Shea in Kadir, 2013). Dunn, Dunn and Burke and Dunn et al. (cited in Kadir, 2013) explained that motivation varies with students' interests and successes, and the degree to which their teachers' styles match their own. Self-motivated students, usually like school and enjoy learning on their own. However, if students lack motivation they will think about their reasons for attending college.

An increasing body of analysis affirms that teaching and advising students with interventions congruent with their learning-style preferences ends up in their enhanced academic achievement and enhanced 
positive attitude towards learning. Further, motivation is one of the central constructs in understanding academic performance and influencing learning strategies. Students with higher motivation levels are more attentive and engaged in their learning than those with lower levels of motivation (Schunk, Meece, \& Pintrich in Hamid \& Singaram, 2016).

\subsection{Conceptual Framework of the Study}

This research employed the constructivist theory as a basis for constructing the research paradigm. Specifically, it According to Meniam et al. (cited in Combalicer, 2016) posits that people learn through a process of constructing meaning utilizing their prior knowledge combined with their experiences. It is supported observation and scientific study that concerns students' way of learning, that is, individuals construct their own understanding and information of the reality through their experiences and reflections on those experiences. People or learners are active creators of their own knowledge through asking questions, exploring and assessing what they know. In addition, the Theory of Intelligences of Howard Gardner was used as a basis of this research. The intelligences such as verballinguistic, logical- mathematical, visual- spatial, auditory- musical, bodily- kinesthetic, interpersonal, intrapersonal, and naturalistic intelligences were investigated and confirmed in the context of the College. The aforementioned theories were used in formulating the research instrument. The schematic diagram below contains the input, process and output of the study.

INPUT

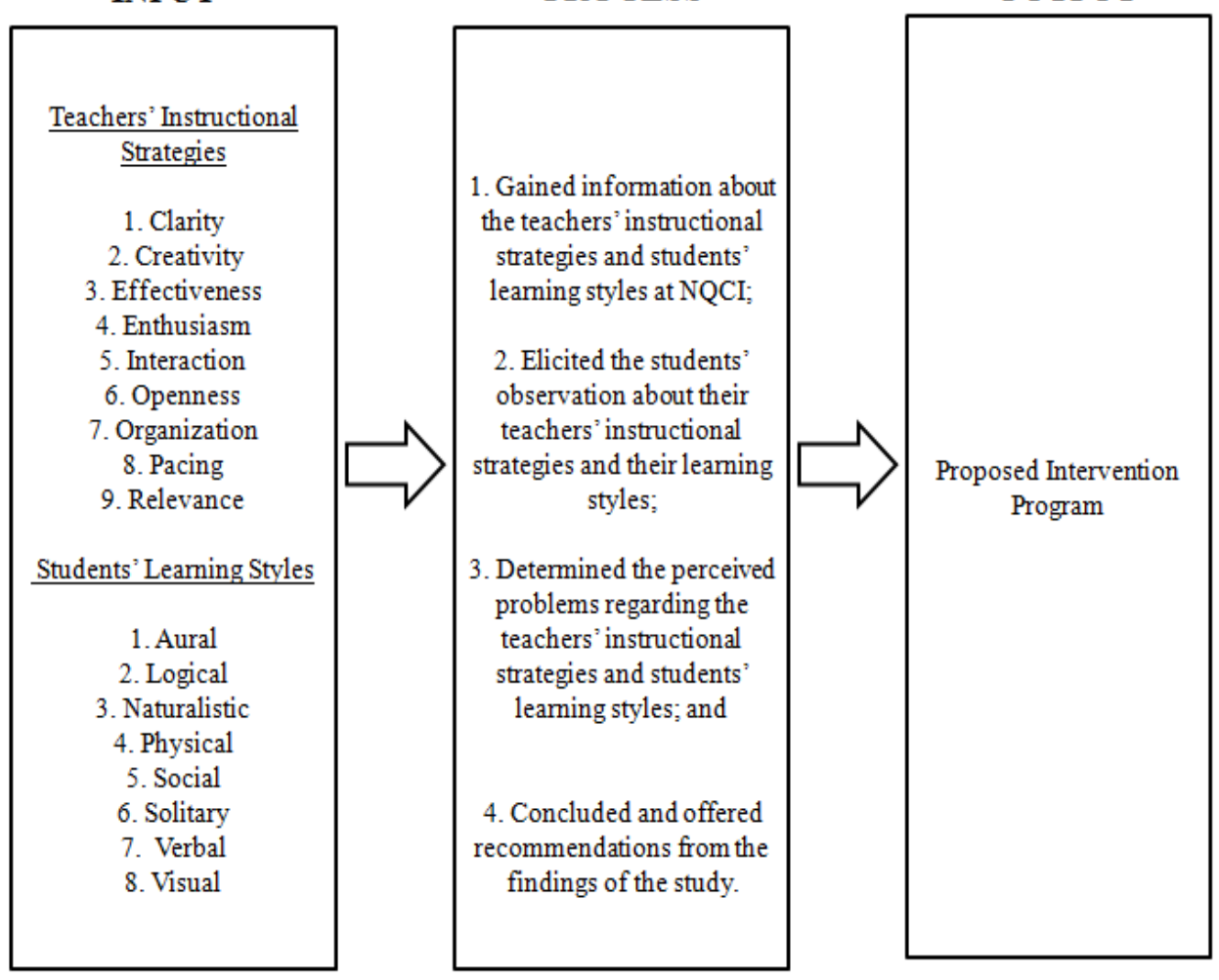

Figure 1. Schematic Diagram of the Conceptual Framework of the Study 


\subsection{Research Design}

The researcher utilized the descriptive-quantitative approach. In this approach, the technique used was the survey method which employed a researcher-validated survey instrument. With the survey method, the respondents indicated their answers concerning the variables. In addition, a set of open-ended questions was formulated which further deepened and concretized the answers of respondents.

Using the Sample Size Formula, the researcher conducted the research with 324 respondents who were selected from 1710 students from Education and Business Administration Department at Northern Quezon College Incorporated. The respondentws were selected randomly through stratefied random sampling.

The researcher utilized a validated researcher-made survey questionnaire with the inclusion of openended questions at the last part of the instrument. The instrument's level of reliability is 0.73 which registered significant at 0.01 level. The statistical formulas used in this study are as follows: percentage, weighted mean, and Pearson Product Moment Correlation Coefficient.

Table 1: The Coefficient of Correlation of the Researcher-Designed

Data Gathering Instrument

\begin{tabular}{|c|c|c|c|}
\hline Paired Scores & r-value & $\begin{array}{c}\text { Magnitude of } \\
\text { Relationship }\end{array}$ & $\begin{array}{c}\text { Level of } \\
\text { Significance }\end{array}$ \\
\hline $\begin{array}{c}\text { Odd Items vs. } \\
\text { Even Items }\end{array}$ & 0.73 & High & 0.01 \\
\hline
\end{tabular}

\section{Findings}

\subsection{Profile of Respondents}

\subsubsection{Age}

The biggest group of student-respondents (142 or 44\%) belonged to the age bracket 19 to 20 . Ninetytwo (92) or $28 \%$ of the students belonged to the 17 to 18 years age bracket while 53 or $16 \%$ of the students belonged to the 21 to 22 years age bracket. With the inclusion of the fourth top-ranked item, the majority age of the student-respondents ranges from 17 to 24 years old.

\subsubsection{Gender}

Out of 324 student-respondents, two hundred fifty-eight (258) or $80 \%$ of the respondents were female and only 66 or $20 \%$ were male. 


\subsubsection{Year Level}

Most of the student-respondents were fourth year and second year students. One hundred eleven (111) or $34 \%$ of the respondents were in their fourth year of schooling and one hundred nine (109) or $34 \%$ were second year students. The least number of students came from the third year.

\subsubsection{Course}

The biggest number of student-respondents belonged to the Bachelor of Science in Business Administration (BSBA) Program. Out of 324 respondents, one hundred seventy (170) or 52\% were BSBA students. On the other hand, one hundred fifty four (154) or $48 \%$ belonged to the Education Programs: Bachelor of Elementary Education; and Bachelor of Secondary Education.

\subsubsection{Residence}

In terms of residence, the majority of the respondents live in Infanta, Quezon. Two hundred thirty four (234) or $72.2 \%$ of the respondents reside in the said municipality. General Nakar, was home to fortytwo (42) respondents or 13\% while Real, Quezon was home to thirty-eight (38) respondents or $11.7 \%$.

\subsection{Instructional Strategies Employed by the Teachers}

\subsubsection{Clarity}

The findings revealed that the majority of the teachers often executed the identified techniques on clarity as instructional strategy. This is based on the average mean score 4.25 which is interpreted as "Often Done".

\subsubsection{Creativity}

With the average mean score of 3.83 and verbally interpreted as "Often Done", the teachers often utilized creativity as an instructional strategy particularly giving students the opportunity to picture out their ideas; using presentable powerpoint presentations; and, coaching students to be creative and innovative in their presentations.

\subsubsection{Enthusiasm}

In general, enthusiasm is often done by the teachers as revealed by the average mean score of 4.10 which is verbally interpreted as "Often Done". Among the eight items, "Encourage students to participate actively" ranked first.

\subsubsection{Openness}

Openness is another instructional strategy which is often utilized by the teachers. It garnered an average mean score of 4.02 which is verbally interpreted as "Often Done". Accepting students' ideas during discussions, accepting new information which are accessed by the students from other reliable sources, acknowledging that the teachers themselves should not limit their students' learning to what they know, 
and intervening whenever students don't respect others' opinions were the strategies employed the teachers in this area.

\subsubsection{Organization}

Organization registered an average mean score of 3.95 which is verbally interpreted as "Often Done" which signifies that the teachers in general often employed the identified tasks on organization as an instructional strategy. Teachers give proper instruction for the presentation and analysis of topics, have proper sequence of activities in delivering lessons, and give assignments for the students to further deepen their learning were the topmost techniques utilized by the teachers on organization.

\subsubsection{Relevance}

Relevance as a teaching strategy was also often done by the teachers. The average mean score of 4.19 which is verbally interpreted as "Often Done" discloses that the teachers primarily connect the topic to real situations in life, relate the lessons in the students' course program, integrate values in the discussions, let the students explain the importance of the topics, and give examples which are contentrelated.

\subsection{The topmost instructional strategies which were often utilized by the teachers are the following:}

- Asking students if the lessons are clear;

- Accepting students' ideas during class discussions;

- Connecting the topics to real situations in life;

- Relating the lessons to the students' course programs, and

- Clearly discussing how the students are graded in their activities or projects.

\subsection{Students' Learning Styles}

\subsubsection{Logical Learning Style}

The average mean score, 3.80, which is verbally interpreted as "Agree" for logical learning style signifies that the students frequently use this style like explaining different opinions, clarifying issues through debate, answering questions through reasoning, challenging the ideas of others, using puzzles and other difficult games to learn, solving mathematical problems, and doing challenging tasks.

\subsubsection{Physical Learning Style}

As revealed by the average mean score, 3.97 which is verbally interpreted as "Agree" the students also frequently use the Physical Learning Style. Therefore, the students enjoy doing activities through body games, learning easily through role playing, understanding lessons through skits, having physical exercises to break dull moments, making diagrams, doing hands-on activities, and exhibiting understanding in skits, dramas and the like. 


\subsubsection{Solitary Learning Style}

As in the case of the afore cited learning styles, the students use the solitary learning style many times as reflected by the average mean score of 3.97 which is verbally interpreted as "Agree". Thus the students keep journals, read books, make individual tasks, study alone, deeply think before giving comments regarding the topic, and prefer to discuss the lessons on a one-on-one basis.

\subsubsection{Verbal Learning Style}

The average mean score for the Verbal Learning Style is 3.84 which is interpreted as "Agree". Therefore, the students also highly enjoy sharing their experiences; giving comments to presentations, ideas and information; reciting poems and other literary work; involving themselves in debate; arguing with classmates about ideas; talking about the topic; telling stories related to the lesson/s; and, discussing problems and their possible solutions.

\subsubsection{Visual Learning Style}

The Visual Learning Style yielded the highest average mean score, 4.20, which is verbally interpreted as "Strongly Agree" which reveals that the students very highly prefer the use of pictures for them to easily understand the lessons, the use of graphic organizers, the use of projected or printed instructions, the use of visual aids as guides when making major projects, taking notes whenever their teachers lecture, the use of colors to highlight important points of the lessons, and using diagrams to remember the main points of the lessons.

\subsection{The Students Very Highly Preferred the Visual Learning Style Specifically:}

- The use of pictures which help them easily understand the lessons;

- Taking notes whenever their teachers deliver a lecture in class;

- The use of graphic organizers helps them a lot;

- Making powerpoint presentations for reports; and

- The use of projected or printed instructions.

\subsection{Correlation of Teachers' Instructional Strategies and Students' Learning Styles}

Table 2: Correlation between Instructional Strategies and Learning Styles

\begin{tabular}{|l|l|l|l|l|}
\hline Variables & $\begin{array}{l}\text { Computed } \\
\text { r- value }\end{array}$ & $\begin{array}{l}\text { Magnitude of } \\
\text { Relationship }\end{array}$ & $\begin{array}{l}\mathrm{p} \text {-value } \\
\alpha=5 \%\end{array}$ & Interpretation \\
\hline $\begin{array}{l}\text { Instructional Strategies } \\
\text { vs } \\
\text { Learning Styles }\end{array}$ & 0.45 & $\begin{array}{l}\text { Marked substantial } \\
\text { relationship }\end{array}$ & 0.00 & $\begin{array}{l}\text { Significantly } \\
\text { related }\end{array}$ \\
\hline
\end{tabular}

Scale: Range of Values by Henry Garrett: 


$$
\begin{array}{ll}
\mathrm{r} \text { from } .00 \text { to } \pm .20 & \text { low, negligible relationship } \\
\mathrm{r} \text { from } \pm .20 \text { to } \pm .40 & \text { present but slight relationship } \\
\mathrm{r} \text { from } \pm .40 \text { to } \pm .70 & \text { marked substantial relationship } \\
\mathrm{r} \text { from } \pm .70 \text { to } \pm 1.00 & \text { high to very high relationship }
\end{array}
$$

The computed coefficient of correlation which is 0.45 denotes a marked substantial relationship based on the range of values which registered significance at the .05 level. Meaning, the teachers' instructional strategies have a substantial relationship with the students' learning styles and registered a significant effect. Therefore, the null hypothesis which states that there is no significant relationship between the teachers' instructional strategies and the students' learning styles, is rejected.

\subsection{Students' Problems Pertaining to Teachers' Instructional Strategies and Students' Learning Styles}

\subsubsection{On Teachers' Instructional Strategies}

Relative to teachers' instructional strategies, the students encountered problems regarding teachers' mastery of the subject matter, skill at the art of questioning, lesson planning, utilization of instructional materials, classroom management, and classroom assessment.

\subsubsection{On Students' Learning Styles}

With regard to their learning styles, the students experienced problems on lack of instructional materials, time for studying, self-confidence, motivation, in-depth understanding on subject matter, communication skills, time management techniques as well as low study habits and attitudes, hectic schedules, information overload and dealing with students with different learning styles.

\section{Conclusions}

The following conclusions are drawn based on the findings of the study:

1. Majority of the student-respondents are 17 to 24 years old, predominantly female, enrolled in the BSBA program, fourth-year college students and reside at Infanta, Quezon.

2. The majority of the teachers frequently utilize all the identified techniques under clarity, creativity, enthusiasm, openness, organization, relevance as instructional strategies.

3. Majority of the students are inclined to the Visual Learning Style however, they also frequently use the logical, physical, solitary, and verbal learning styles thus, they mix all the learning styles together in their studies depending on the requirements of the subject matter.

4. The teachers' instructional strategies are significantly related to the students' learning styles. If teachers' instructional strategies are effective then students' learning styles are also effective.

5. On Teachers' Instructional Strategies, the students are beset with problems on teachers' mastery of the subject matter, skill at the art of questioning, lesson planning, utilization of instructional materials, classroom management, and classroom assessment while on their learning styles they are also beset with problems on lack of instructional materials, time for studying, self- 
confidence, motivation, in-depth understanding on subject matter, communication skills, time management techniques as well as low study habits and attitudes, hectic schedules, information overload and dealing with students with different learning styles.

6. The proposed intervention program on faculty development is concrete, relevant, functional and responsive.

\section{Recommendations}

Based on the findings of the study and conclusions, the following are highly recommended:

1. The school administration needs to regularly conduct trainings, seminar-workshops, and orientations to reinforce the teachers' motivation and skill in using different instructional strategies. Experts may be invited to discuss the following topics:

- Art of Questioning;

- Best Practices in Teaching College Students;

- Bloom's Taxonomy of Learning;

- Contemporary Teaching Strategies;

- Effective Classroom Management;

- Educational Technology and Information and Communications Technology;

- Students' Learning Styles;

- Teachers' Instructional Strategies;

- The Teaching Profession;

- Theory of Multiple Intelligences; and

- Test and Test Construction.

2. They should also prioritize the purchase of indispensable instructional materials such as projectors, speakers and the like. The General Services Department should craft policies for an effective management of instructional materials to avoid waste of time and damage to facilities. In addition, supervision of instruction should be made by the respective Department Heads of the College through observation of classes with the help of the coordinators who have a wide knowledge in the subject areas. This is to make sure that students' learning is prioritized through effective delivery of instruction.

3. The teachers need to attend on-campus and off-campus seminar-workshops, trainings and conferences particularly on enhancing their instructional strategies and intensifying their understanding of students' learning styles especially that they are now dealing with digital natives or millennial learners. They should seek membership in professional associations to be able to attend to the seminar-workshops and trainings sponsored by such and to avail of updated instructional materials given out.

4. The Commission on Higher Education should do close regular monitoring to assist in addressing the weakness areas of the college particularly on faculty qualifications, facilities and instructional materials. 
5. The Research Committee of Northern Quezon College Incorporated should conduct researches concerning other variables that affect teachers' instructional strategies and students' learning styles. Following are the recommended topics for further research:

- Best practices in teaching college students: implications to effective college teaching

- The effects of instructional materials in teaching college students

- Technology integration in college instruction

- Educational games as an instructional strategy in college instruction

- Classroom management and its relation to the academic performance of college students: basis for an intervention program

\section{The Proposed Faculty Development Program}

Table 3: The proposed program

\begin{tabular}{|c|c|c|c|c|}
\hline $\begin{array}{c}\text { Goals/ } \\
\text { Objectives }\end{array}$ & Strategies/ Activities & Time Frame & $\begin{array}{c}\text { Financial } \\
\text { Requirement }\end{array}$ & $\begin{array}{l}\text { Expected Output/ } \\
\text { Outcomes }\end{array}$ \\
\hline $\begin{array}{l}\text { Continuing in- } \\
\text { service } \\
\text { training for } \\
\text { faculty } \\
\text { members }\end{array}$ & $\begin{array}{l}\text { 1. Conduct in-house } \\
\text { trainings for faculty } \\
\text { members on the } \\
\text { following: } \\
\text { a. updates on } \\
\text { contemporary teaching } \\
\text { strategies; } \\
\text { b. art of questioning; } \\
\text { c. instructional } \\
\text { planning; } \\
\text { d. classroom } \\
\text { management skills; }\end{array}$ & $\begin{array}{l}\text { First } \\
\text { Semester of } \\
\text { Schoolyear } \\
\text { 2017- } 2018\end{array}$ & PhP 20, 000 & $\begin{array}{l}\text { 1. The Faculty } \\
\text { Members are more } \\
\text { knowledgeable and } \\
\text { well- equipped } \\
\text { with skills in } \\
\text { a. utilizing } \\
\text { appropriate } \\
\text { instructional } \\
\text { strategies; } \\
\text { b. skill in the art of } \\
\text { questioning; } \\
\text { c. syllabi making or } \\
\text { lesson planning; } \\
\text { d. using appropriate } \\
\text { classroom } \\
\text { management } \\
\text { strategies; } \\
\text { e. assessing } \\
\text { learning before, } \\
\text { during, and after } \\
\text { instruction; } \\
\text { f. integrating } \\
\text { educational } \\
\text { technology in }\end{array}$ \\
\hline
\end{tabular}




\begin{tabular}{|c|c|c|c|c|}
\hline & $\begin{array}{l}\text { f. use of educational } \\
\text { technology in teaching; } \\
\text { g. learning styles and } \\
\text { multiple intelligences; } \\
\text { 2. Invite a pool of } \\
\text { experts to facilitate } \\
\text { seminars and trainings } \\
\text { on the different areas of } \\
\text { specialization }\end{array}$ & $\begin{array}{l}\text { August } \\
\text { 2017- } 2018\end{array}$ & PhP 100, 000 & $\begin{array}{l}\text { teaching; and } \\
\text { g. understanding } \\
\text { the nature of } \\
\text { learners by } \\
\text { analyzing their } \\
\text { learning styles or } \\
\text { individual } \\
\text { differences. } \\
\text { 2. The faculty are } \\
\text { more } \\
\text { knowledgeable on } \\
\text { the contents of the } \\
\text { lessons. }\end{array}$ \\
\hline $\begin{array}{l}\text { Ensuring the } \\
\text { sufficiency of } \\
\text { instructional } \\
\text { materials for } \\
\text { the effective } \\
\text { delivery of } \\
\text { instruction }\end{array}$ & $\begin{array}{l}\text { Purchase necessary } \\
\text { facilities such as } \\
\text { computers, projectors, } \\
\text { speakers, white screens, } \\
\text { white boards, and } \\
\text { printing machines for } \\
\text { production of print- outs }\end{array}$ & $\begin{array}{l}\text { First } \\
\text { Semester of } \\
\text { Schoolyear } \\
\text { 2017- } 2018\end{array}$ & PhP 200, 000 & $\begin{array}{l}\text { Functional and } \\
\text { updated } \\
\text { instructional } \\
\text { facilities }\end{array}$ \\
\hline $\begin{array}{l}\text { Maintaining } \\
\text { Well-Guided } \\
\text { Teaching } \\
\text { Practices }\end{array}$ & $\begin{array}{l}\text { 1. Require the } \\
\text { Department Heads to } \\
\text { supervise the faculty } \\
\text { members by: } \\
\text { a. daily observation of } \\
\text { classroom activities; } \\
\text { b. reviewing the } \\
\text { learning plans (e.g. } \\
\text { syllabi); } \\
\text { c. mentoring or } \\
\text { advising. } \\
\text { 2. Formulate a valid and } \\
\text { reliable instrument for } \\
\text { monitoring or }\end{array}$ & $\begin{array}{l}\text { Continuous } \\
\text { Continuous } \\
\text { Continuous } \\
\text { June } 2017\end{array}$ & $\mathrm{PhP} 5,000$ & $\begin{array}{l}\text { a. Effective } \\
\text { supervision of } \\
\text { classroom activities } \\
\text { b. Instructional } \\
\text { plans are well- } \\
\text { reviewed } \\
\text { c. Faculty } \\
\text { members' teaching } \\
\text { strategies are } \\
\text { improved } \\
\text { A functional } \\
\text { monitoring } \\
\text { instrument is used }\end{array}$ \\
\hline
\end{tabular}




\begin{tabular}{|c|c|c|c|c|}
\hline & $\begin{array}{l}\text { observation of teachers' } \\
\text { instructional strategies. } \\
\text { 3. Benchmark with } \\
\text { universities which are } \\
\text { Centers of Excellence } \\
\text { (COE) or Centers of } \\
\text { Development (COD) in } \\
\text { teaching re: } \\
\text { andragogical approaches } \\
\text { and contemporary } \\
\text { teaching strategies. } \\
\text { 4. Use students' } \\
\text { evaluation of teaching } \\
\text { performance as one of } \\
\text { the bases for loading of } \\
\text { subjects. }\end{array}$ & $\begin{array}{l}\text { July } 2017 \\
\\
\text { June } 2017 \\
\text { (For the First } \\
\text { Semester) } \\
\text { and } \\
\text { November } \\
\text { 2017 (For the } \\
\text { Second } \\
\text { Semester) }\end{array}$ & $\mathrm{PhP} 20,000$ & $\begin{array}{l}\text { for regular } \\
\text { observation of } \\
\text { instructional } \\
\text { strategies. } \\
\text { 3. The Faculty are } \\
\text { informed about the } \\
\text { best practices of } \\
\text { well- known } \\
\text { universities re: } \\
\text { instructional } \\
\text { strategies } \\
\text { Correct loading of } \\
\text { subjects }\end{array}$ \\
\hline $\begin{array}{l}\text { Instituting a } \\
\text { scientific and } \\
\text { standardized } \\
\text { system of } \\
\text { giving awards } \\
\text { and incentives } \\
\text { to faculty with } \\
\text { outstanding } \\
\text { teaching } \\
\text { performance }\end{array}$ & $\begin{array}{l}\text { 1. Construct and } \\
\text { validate an instrument to } \\
\text { evaluate outstanding } \\
\text { teaching performance } \\
\text { 2. Evaluate outstanding } \\
\text { teaching performance } \\
\text { using the validated } \\
\text { instrument }\end{array}$ & $\begin{array}{l} \\
\text { September } \\
2017 \text { (For the } \\
\text { First } \\
\text { Semester) } \\
\text { and } \\
\text { February } \\
2018 \text { (For the } \\
\text { Second } \\
\text { Semester) }\end{array}$ & Php 100,000 & $\begin{array}{l}\text { 1. Functional } \\
\text { instrument for the } \\
\text { evaluation of } \\
\text { teaching } \\
\text { performance } \\
\text { Well- performing } \\
\text { and motivated } \\
\text { Faculty Members }\end{array}$ \\
\hline $\begin{array}{l}\text { Continuing } \\
\text { Professional } \\
\text { Development }\end{array}$ & $\begin{array}{l}\text { 1. Encourage the faculty } \\
\text { members to enrol in } \\
\text { graduate studies or post- }\end{array}$ & Continuous & Php 100,000 & $\begin{array}{l}\text { 1. The number of } \\
\text { faculty members } \\
\text { who are enrolled in }\end{array}$ \\
\hline
\end{tabular}




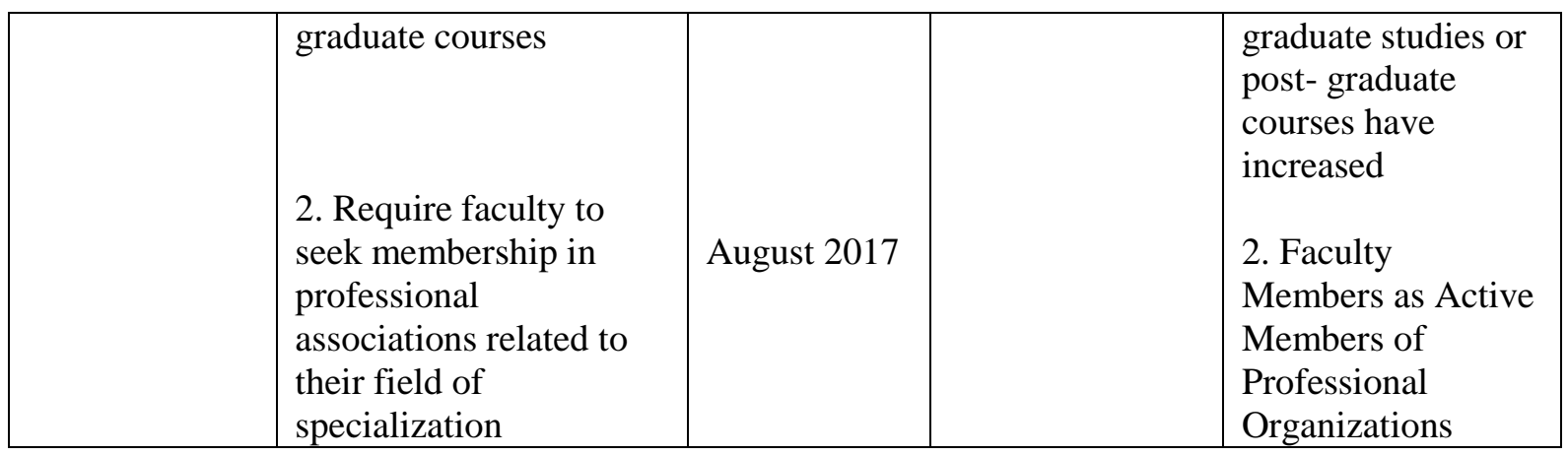

\section{References}

Academic Council of Northern Quezon College, I. (2016). Revised Student Handbook. Infanta, Quezon. Asadipiran, N. (2016). Identifying young learners' learning styles among Iranian EFL Learners. ProQuests, 1444- 1450.

Instructional Strategies Motivate and Engage Students in Deeper Learning. (2013, April). N.W. Atlanta, United States of America. Retrieved from SREB: http://www. sreb.org

Combalicer, L. (2016). Best practices and problems in the initial implementation of the K+12

Currciulum among teachers in Infanta, Quezon: Implications to an effective implementation of Senior High School. Journal of Education and Social Science, 4, 1-17.

Eison, J. (2010, March). Retrieved September 8, 2016, from http://www.cte.cornell.edu/documents/presentations/Eisen-Houndout.pdf

Eison, J. (2010, March). Using active learning instructional strategies to create excitement and enhance learning. Retrieved September 8, 2016

Kadir, M. B. (2013). The Relationship between students' learning style and academic performance in Mara Professional College, Malaysia. The Asian Conference on Education 2013. Osaka, Japan: Official Conference Proceedings.

Nosratinia, M. \& Soleimannejad, A. (June 2016). Perceptual learning styles and critical thinking: Inspecting the association among EFL learners. ProQuests, 1220- 1228.

Palos, R., Munteanu, A., Costea, I., \& Macsinga, I. (2011 ). Motivational and cognitive variables with impact on academic performance preliminary study. Procedia-Social and Behavioral Sciences, 15, 138-142.

Taheri, M., Nasiri, E., Maddab, F., Nayebi, N., \& Louyeh, A. A. (2015). Strategies to improve students' educational achievement motivation at Guilan University of Medical Sciences. Research and Development in Medical Education, 4(2), 133-139. 